This item was submitted to Loughborough's Research Repository by the author.

Items in Figshare are protected by copyright, with all rights reserved, unless otherwise indicated.

\title{
The region in political economy
}

PLEASE CITE THE PUBLISHED VERSION

PUBLISHER

(C) Blackwell Publishing

VERSION

AM (Accepted Manuscript)

LICENCE

CC BY-NC-ND 4.0

REPOSITORY RECORD

Harrison, John. 2019. "The Region in Political Economy”. figshare. https://hdl.handle.net/2134/4401. 
This item was submitted to Loughborough's Institutional Repository (https://dspace.lboro.ac.uk/) by the author and is made available under the following Creative Commons Licence conditions.

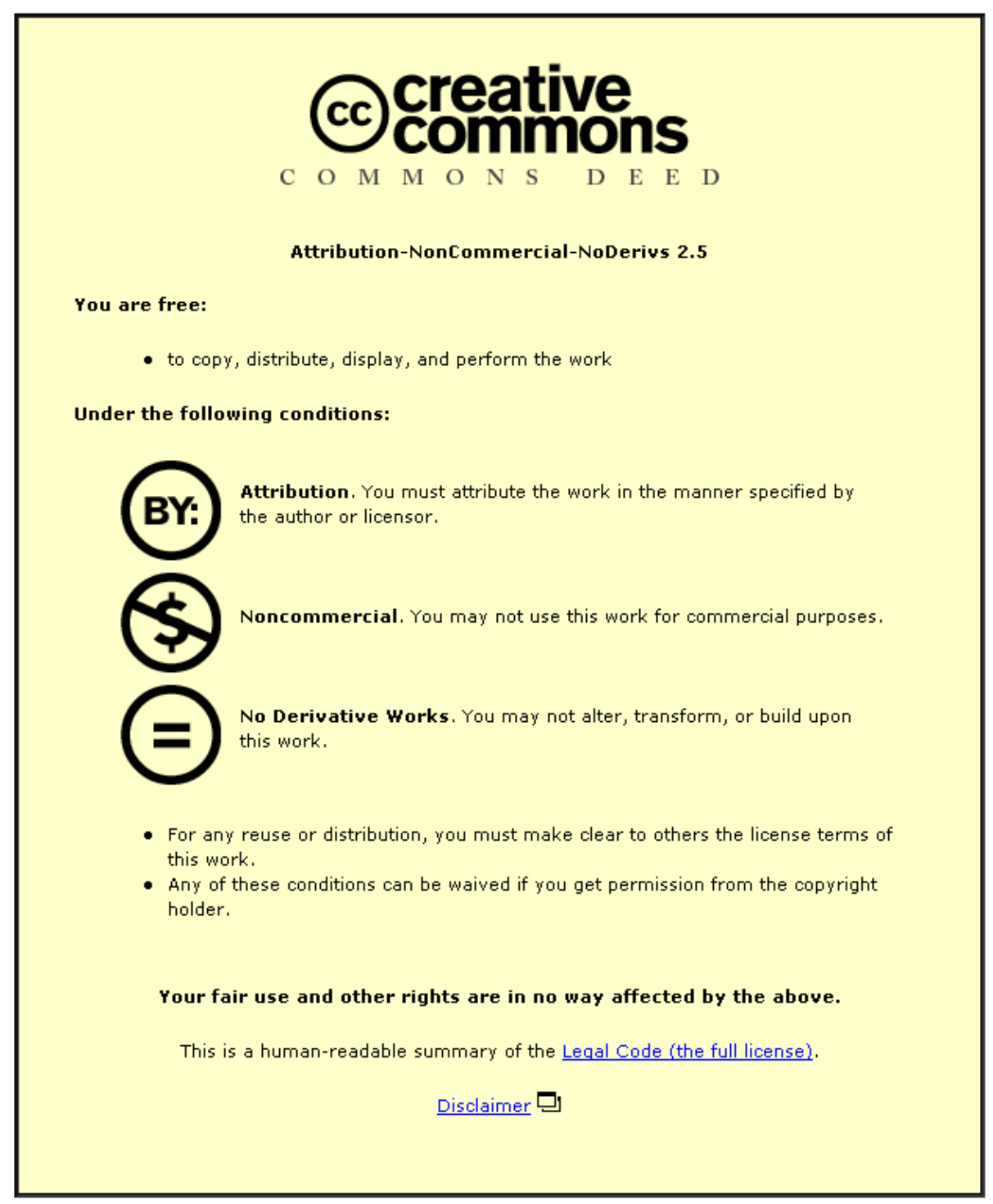

For the full text of this licence, please go to: http://creativecommons.org/licenses/by-nc-nd/2.5/ 


\title{
THE REGION IN POLITICAL ECONOMY
}

\section{JOHN HARRISON}

\author{
DEPARTMENT OF GEOGRAPHY \\ LOUGHBOROUGH UNIVERSITY \\ LOUGHBOROUGH \\ LEICESTERSHIRE \\ ENGLAND \\ LE11 3TU \\ J.HARRISON4@LBORO.AC.UK
}

$\mathrm{T}:+44(0) 1509228198$

$F:+44(0) 1509223930$

Paper re-submitted to Geography Compass

February 2008 
5 A decade ago regions were the hot topic in political economy. Convinced by

6 accounts of how regions were competitive economic territories per excellence

7 and crucial sites for promoting a plural society, the 'new regionalism'

8 ascended to a position of orthodoxy in political economy. Today the memory

9 of these halcyon days is but a distant one with the past decade seeing regions

10 be the site for a number of topical debates which appear at first sight to

11 challenge the regional concept: the collapse of the new regionalist orthodoxy;

12 the theoretical ascendancy of relational approaches to conceptualising

13 spatiality; and, the political ascendancy of the 'city-region' concept. All of 14 which suggests that the regional concept may be under threat in 15 contemporary political economy. But it also prompts the need to confront 16 searching questions as to whether we are in fact witnessing the awakening of

17 a new geography of the region. This paper emphasises the latter, arguing that 18 what we are witnessing is the emergence of a new era of 'relational 19 regionalism' in political economy. 
Introduction: the new regionalist orthodoxy

A decade ago regions were the hot topic in political economy. Under the

banners of 'regional political economy' and the 'new regionalism' writers and

commentators noted how the rise of dense vertically disintegrated industrial districts, such as Baden-Württemberg, Emilia Romagna, and Silicon Valley, presented the region as the focal point of post-Fordist, flexible, learning-based

57 production systems - the emerging face of capitalist accumulation. Convinced by accounts of how regions were competitive economic territories par 59 excellence, academics, political leaders, and practitioners increasingly 60 believed that we were living in a 'regional world' - with regional economies the 
61 building blocks for a globally networked society (Storper 1997). Territorial

62 platforms from which growth and prosperity accumulated in the post-Fordist

63 economy, regions were also deemed a crucial site for promoting a plural

64 society, centred on participatory democracy, active citizenship, and civic pride

65 (Keating 1998, Putnam 1993). Promoting the dual dividend of economic

66 prosperity and democratic renewal, the new regionalism ascended to a

67 position of orthodoxy in the study of political economy, offering both a

68 "convincing theoretical explanation of recent and future regional economic

69 development and also the best approach to policy formation" (Lovering 1999, $70380)$.

71 Today though, the memory of these halcyon days is a distant one. Not

72 the fashionable banner that it once was, the latest annals of political economy

73 no longer has the 'rise of the region' as its cover story. First, the conceptual

74 standing of the new regionalism has been eroded, with critics arguing that the

75 orthodoxy afforded to the region was achieved without sustained rational

76 theorisation and rigorous empirical testing (Lovering 1999). Second, the

77 notion of regions as territorially bound spatial/scalar entities has been

78 theoretically challenged by those advocating a relational approach to spatiality

79 - the notion that there cannot be a single 'essential' definition of a concept

80 (e.g. the region) since its meaning can only be defined by its relational context

81 (Allen et al 1998). Thus, depending upon your position, the merits of

82 scalar/territorial approaches have been challenged, flanked, overtaken, or

83 replaced by relational approaches to understanding sociospatiality. Meanwhile

84 and related to this, the emergence of newer state spaces have also presented

85 a threat to regions (Brenner 2004). Notable here has been the (re-)emergence 
of the 'city-region concept' (Scott 2001) and the ongoing debate within political economy as to how city-regions relate to/differ from regions (see Harrison, 2007). All of which suggests that the 'regional concept' may be under threat both theoretically and politically at the beginning of the twenty-first century.

But it also prompts the need to confront searching questions as to whether

91 what we are witnessing is actually the regional concept under threat, or the awakening of a new geography of the region in political economy.

A decade ago the task of fielding questions on the position, role, and future of the region in political economy would have proved a relatively painless exercise, with regional geographers (in particular new regionalists) seen to be at the forefront of dynamic research debates on deciphering the new politics of economic development with transitions in the regulation and governance of contemporary capitalism and its territorial configuration. Notions that we were living in a 'regional world' were suggestive of a bright 100 future. Yet with the benefit of hindsight, the new regionalist orthodoxy of 101 1990s was not the stable foundation that many assumed it to be. As is often 102 the case, the strengths which enabled the new regionalism to ascend to such 103 a lofty position within political economy would prove to be its undoing. Under 104 threat theoretically and politically, the future of the region appears less clear in 105 present day political economy. And yet, it could be that the regional concept is 106 stronger now than it was a decade ago.

This paper argues that while the region has been under threat over the 108 past decade, this does not presuppose its erosion from political economy. 109 Rather it is suggested that it marks the emergence of a new geography of the 110 region based upon new developments in the study of state spatiality, which 
111 may at first appear to threaten the regional concept, but which serve to

112 highlight its importance in political economy. To illustrate this, the paper

113 begins by recounting the rise and fall of the regional concept. In particular it

114 details how the regional concept has repeatedly reinvented itself, constantly

115 shifting its focus to accommodate, and be accommodated by, the evolving

116 discipline of geography and perhaps most importantly, the changing nature of

117 the world that regionalists decipher and conceptualise. In essence, history

118 suggests that when the regional concept has been under threat, it emerges

119 from this as a much stronger and more robust concept. This paper

120 investigates whether this trend is likely to continue in light of emerging and

121 perceived threats to the study of regions in political economy.

123 The rise and fall of the regional concept ${ }^{\mathrm{i}}$

124 Of intrinsic value to a number of academic disciplines, it is with the discipline 125 of geography that the region is most commonly associated. The focus of its 126 own particular branch of the discipline, 'regional geography' has been an ever127 present sub-discipline of geography, and as such, integral to the development 128 of the geographical discipline. However, this long and distinguished history of 129 regions in geography should not belie the fact that the regional concept has 130 also endured some challenging times. Yet it is from these challenging times 131 that the region has emerged a stronger and more robust concept. Indeed it is 132 suggested here that the rise and fall of the regional concept in geography 133 holds important pointers for understanding the current role for regions in 134 political economic debate. 
Pioneering work by Herbertson (1905), Fleure (1919), and Vidal de la Blache (1926) on the particular nature of individual regions, and later Hartshorne $(1939,1959)$ on the nature of geography as a regional discipline, ensured that regional geography flourished in the first half of the twentieth

139 century. Establishing itself with its own regional tradition in geography, this 140 understanding of the region was, however, to come under threat during the 141 postwar years with the advent of spatial science and the search for laws of 142 spatial behaviour. Standing in opposition to the established 'regional 143 geography' of the time, the advance of spatial science presented itself as a 144 real threat to the future of the regional concept in geography. But what was 145 first perceived as a threat was to mark the birth of a new brand of regional 146 geography.

147 Highlighting the functionality of regions (Haggett 1965, Isard 1960) and 148 their practical importance in postwar planning, the emergence of a new 149 scientific regional geography contributed to the recognition that the regional 150 concept was the fundamental backdrop for all geographical studies (Dickinson 151 1976). Yet following the steady drift away from (regional) spatial science in the 152 1970s, the regional concept was soon seen to be of diminishing theoretical 153 and practical use (Holland 1976). One commentator even went so far as to 154 suggest that regional geographers were the 'last of the handloom weavers' 155 (Paterson 1974) - a group with little or nothing to offer a discipline that was 156 broadening its horizons, incorporating new and exciting developments in 157 critical geography, and leaving traditional geography (of which regional 158 geography was a bastion) behind. The regional concept was, in other words, 159 past its sell by date. And yet in the three decades that have passed since this 
view was first expressed the regional concept has remained central to the

161 advancement of the geographical discipline.

Regional geography was not only to survive the threats of the 1970 s,

163 but it was to become the vehicle through which many of these new debates

164 took shape. First the work of Marxist inspired academics focused attention on

165 the region once more as they sought to explain how regional variation was

166 intricately bound up with capitalist accumulation, and from this, how economic

167 activity responded to geographical inequality in the conditions of accumulation

168 (Harvey 1982, Massey 1978, 1979, 1984). And second, advances in cultural

169 geography alongside geographers' deeper concern with place - the social

170 construction of place, and human subjects sense of place and emotional

171 attachment to place - led to a 'new regional geography', which conceptualised

172 regions as the meeting place for systems of culture, politics, and economy to

173 coalesce at different spatial and territorial scales. Radically different from the

174 previous tendency to view space as passive, the 'new regional geography' of

175 the 1980s contributed to wider debates on how spatial difference was not

176 simply an outcome but integral to the constitution and reproduction of society

177 (Gilbert, 1988). Contributing to a vibrant debate on how regions are formed

178 and subsequently develop unevenly, the 'new regional geography' has

179 become somewhat overshadowed in recent years by debates pertaining to a

180 'new regionalism' in economic development and territorial representation. With

181 its claim that the region, and not the nation-state, was the key site at which 182 economic management was to be conducted, social welfare delivered, and for 183 political subjects to be citizens, the new regionalism became the buzzword for 184 political-economists in the mid-to-late-1990s. From academic discussions and 
185 scholarly writings to political pamphlets and policy documents, the new 186 regionalism quickly gained a captive audience such that its architects were not 187 only lauded for their insight, they became authorities on connecting the new 188 politics of economic development with transitions in the regulation and 189 governance of contemporary capitalism and its territorial form. Across North 190 America and Western Europe, moves to devise policies to embrace the 191 orthodoxy surrounding the new regionalism became an institutionalised task. Today the memory of these halcyon days is a distant one with the so193 called 'rise of the region' no longer to the fore in political economy. Over the 194 past decade growing academic concern over the conceptual standing of the 195 new regionalism has been fuelled by further reflection on the events and 196 processes occurring in Baden-Württemberg, Emilia Romagna, and Silicon 197 Valley, but more particularly, the relative success and failure of policy 198 measures devised to copy the success of these so-called 'exemplar regions' 199 in gaining competitive advantage in the global economy (Christopherson 200 2003, Harrison 2006, Jones 2001, Lovering 1999, MacLeod 2001b). As a 201 result, the past decade has seen the region become the subject for a number 202 of topical debates - some theoretical, some methodological, and some 203 political - which have highlighted a number of potential and/or existing threats 204 to its continued relevance in political economy.

206 Regions under threat?

207 While a wide range of potential and/or existing threats could have been 208 highlighted here, there are three that appear particularly noteworthy and 209 warrant closer examination: the collapse of the new regionalist orthodoxy; the 
210 theoretical ascendancy of relational approaches in conceptualising spatiality;

211 and, the advance of city-regions in the political praxis and development

212 planning of countries throughout North America, Western Europe, even parts

213 of the developing world (OECD 2007, Scott 2001, Segbers 2007, Simmonds

214 and Hack 2000). The next section explores each in turn.

215

216 The collapse of the new regionalist orthodoxy

217 At the end of the twentieth century the new regionalism had reached a 218 crossroads. For no sooner had the new regionalism reached its zenith in 219 political economy than its orthodoxy began to wane. Points of weakness were 220 beginning to emerge and the conceptual standing of the new regionalism was 221 beginning to weaken. Of these points of weakness, four are particularly 222 noteworthy. First, the new regionalism was deemed an extremely "chaotic 223 concept' (Sayer 1992) that bundled together too many diverse theories for it to 224 be considered a coherent body of work. For the region was not just a focal 225 point for geographers at this time, but also for business gurus, economists, 226 political scientists and the like. The result was a perceived lack of engagement 227 and consistency in the application of what was actually meant to be the object 228 of focus - the region. Second, and barring a few exceptions, the new 229 regionalism was seen to have "disregarded the changing role of the state or 230 implied that, amid the current round of globalisation-regionalisation, it was 231 inevitably in terminal decline" (MacLeod 2001a, 806). Third, the new 232 regionalism was identified as becoming enmeshed in multifaceted scalar 233 politics and tangled policy hierarchies. And finally to paraphrase Lovering 234 (1999), it was suggested that the policy tail was wagging the analytical dog so 
235 hard that much of the theory was being shaken out of the new regionalism.

236 Not just superficial scars, these critical points of weakness undermined the

237 very foundation upon which the new regionalism had been conceptually

238 constructed. As the twentieth century drew to a close a low point had clearly

239 been reached in the new regionalism.

240 Yet through the work of a new generation of theorists, a second wave

241 of research emerged which sought to provide new insight into the 'rise of the

242 region' in political economy. Heavily influenced by the Regulation Approach

243 this new body of work acknowledged how the rise of the regional state was

244 not necessarily or purposively at the expense of the state, but as a new form

245 of 'spatial selectivity' by the state (Brenner 2004, Brenner et al 2003, Jones

246 2001, MacLeod 2001a, 2001b, MacLeod and Goodwin 1999a, 1999b). Less

247 eye-catching and politically savvy than predecessor writings in the new

248 regionalism, this political economy approach to the study of regions solidified

249 the conceptual standing of the new regionalism by unpacking the territorial

250 and scalar relationships that existed between regions and other spaces/scales

251 of political economy activity. Heavily influenced by the levels of state

252 restructuring occurring in the United Kingdom, this political economy

253 perspective was indicative of the complex dynamics of territorial restructuring

254 and political change occurring throughout Europe at the time (Bache 1998,

255 Hooghe 1996).

256 Informing how political-administrative regions are strategic territories in 257 the reconstituted governance of contemporary capitalism, these 258 territorial/scalar approaches were seen to take the new regionalism and 259 regional political economy from a position of conceptual weakness to a 
position of (relative) conceptual strength. But for all that this new body of work

261 has done to provide new insight, it too has come under threat recently from

262 those advocating relational approaches to conceptualising spatiality.

264 The relational approach to conceptualising spatiality

265 For a regional geographer the hardest questions to answer focus on the very 266 nature of their object of inquiry. There is no easy answer to the question: What 267 is a region? Nor for that matter are there easy answers to the questions: How 268 is a region (trans)formed? Why do regions (dis)appear over time? Why do 269 regions emerge in certain places at certain times, and not in other places? All 270 fundamental questions that face the regional geographer on a day-to-day 271 basis, but at the same time they are not easy questions to answer. Of the four 272 points of weakness highlighted in the new regionalism it is the first - the 273 chaotic nature of lack of consistency with what is meant by 'the region' - that 274 is the most fundamental, but also the most difficult to overcome. But what of 275 the new regionalism and its lack of engagement with the 'region'.

At one level, the dominant strand of new regionalist thinking 277 popularised in economic geography (Scott 1998, Scott and Storper 2003, 278 Storper 1997) led to claims that the region was the territorial platform for 279 securing competitive advantage in the global economy. Regions were given 280 single 'essential' definitions and lauded as the fundamental building blocks of 281 a 'regional world' (Storper 1997). By way of contrast, a second strand of new 282 regionalist thinking popularised in the writings of political-scientists such as 283 Keating (1998) acknowledged the variety of regions (cultural, economic, 284 administrative, political, governmental etc) and how they are fundamentally 
different, but then fell back into the 'essentialist' trap of focusing primarily on

286 regions as actually existing political and/or governmental units. A weakness

287 across the new regionalist writings, the region was an easy target for those 288 advocating a relational approach to conceptualising spatiality.

289 More than statistically or administratively convenient constructs, 290 advocates of the relational approach to conceptualising spatiality argue that 291 there are no fixed, pre-existing regions 'out there waiting to be discovered', 292 but that regions take shape in particular contexts and from specific 293 perspectives (Allen et al 1998, 2). Written at the height of the new regionalist 294 orthodoxy, Allen et al's pioneering study of south east England demonstrated 295 the analytical capacity of relational perspectives when, having analyzed four 296 different mechanisms of growth (finance, consumption and debt, high 297 technology, and state policies), they noted how the boundaries of the region 298 varied depending upon which mechanism of growth was being analysed, and 299 moreover, how none coincided with the region's official administrative 300 boundary. Over the past decade, this and subsequent work on relational 301 thinking has resulted in the emergence of a new 'spatial grammar'. Suggestions that we are living in a 'regional world' (Storper 1997) and 303 single 'essential' definitions of the region have been put firmly into the 304 shadows by the recognition that spatial configurations are not necessarily or 305 purposively territorial or scalar, but constituted through the spatiality of flow, 306 porosity, and relational connectivity associated with globalization (Amin et al 307 2003, Geografiska Annaler 2004, Massey 2005). In a relationally constituted 308 modern world, capital accumulation and governance is deemed to be 309 "increasingly about exercising nodal power and aligning networks at large in 
one's own interests, rather than about exercising territorial power...[for] there

311 is no definable regional territory to rule over" (Amin 2004, 36). As a result, a

312 lively debate exists between those who advocate territorial/scalar approaches

313 to conceptualising spatiality and those advocating a relational approach. All of

314 which is presenting a real challenge to those analysing regions. But it also

315 prompts the question of whether the 'relational turn' is presenting an

316 opportunity for regions to be a focal point in the empirical demonstration and

317 theoretical amendment of the way(s) in which space is currently

318 conceptualised. Indeed, it can be seen that regions are already proving to be

319 an important object of inquiry in the development of these theoretical debates.

320 Already noted to be central players in the development of a political

321 economy approach to the study of regions, MacLeod and Jones (2001)

322 observed that while the new regionalism had done much to revive debate

323 about regional change, it concealed fundamental questions relating to political

324 struggles and the contested social and cultural practices through which

325 societies assume their regional shape. Drawing inspiration from work in the

326 'new regional geography' tradition (most notably Paasi 1986), MacLeod and

327 Jones $(2001,669)$ argued the need for a 'renewed geography of regions' to

328 unravel the culturally embedded institutionalisation of regions and advance a

329 meaningful understanding of regional change.

330 As part of their ongoing endeavour to renew the geography of regions,

331 Jones and MacLeod (2004) have recently drawn distinction between 'regional 332 spaces' and 'spaces of regionalism' - the former referring to the 333 regionalization of economic activity; the latter to processes of political 334 mobilization around notions of increased civic identity and cultural expression. 
335 Rather than see the conceptualisation of spatiality in either/or terms, Jones 336 and MacLeod $(2004,437)$ argue that relational accounts are most convincing 337 when they focus on "economic flows and interchange" but that they "bend the 338 stick too far" when it comes to spaces of political regionalism where "political 339 action' is mobilised territorially (cf. Amin et al 2003, Allen and Cochrane 2007). 340 So rather than adopt a territorial/scalar or networked/topological 341 conceptualisation of spatiality, Jones and MacLeod argue for "a retaining of 342 territorially oriented readings of political economy and when appropriate their 343 conjoining with non-territorial and/or relational socio-economic and political 344 strategies" (2004, 448 emphasis added, see also Hudson 2007, MacLeod and 345 Jones, 2007). Looking beyond the confines of regional geography for one moment,

347 this position appears to be supported by a number of other influential 348 geographical commentators. Work on deciphering the geographical nature of 349 the 'global economy' by Dicken et al (2001, 96-97) suggests that adopting a 350 networked approach to analyzing the economy should not lead us to 351 "denigrate the role of the territorial state in global economic processes" 352 because "national regimes of accumulation continue to create a pattern of 353 'bounded regions"' such that territories and networks interact in a "mutually 354 constitutive process". Swyngedouw $(2004,25)$ adopts a similar view, arguing 355 that "both the scales of economic flows and networks and those of territorial 356 governance are rescaled through a process of 'glocalisation'...[such that] the 357 proliferation of new modes and forms of resistance to the restless process of 358 de-territorialisation/re-territorialisation of capital requires greater attention to 359 engaging a 'politics of scale'". In step with Jones and MacLeod's (2004) 
distinction between politics and economics, and thus how these spaces are

361 conceptualised, "the clear implication is that they operate according to

362 different kinds of logic and in relation to distinct domains: economic flows in

363 the case of networks and political institutions in the case of territories" (Painter

$3642007,6)$.

365 Yet a number of leading geographical commentators remain firmly

366 rooted to positions which challenge the notion that spatiality should be

367 conceptualised as territorial/scalar - instead preferring to distance themselves

368 completely from territorial/scalar conceptualisations of spatiality. The most

369 striking element of this collective of academics is the shear diversity of

370 intellectual backgrounds and research agendas that have come together to

371 form this scholarly commune. Now it is clearly a difficult task - one that

372 stretches far beyond the capabilities of a paper such as this - to adequately

373 cover the full spectrum of approaches that have been developed to

374 theoretically speculate, empirically demonstrate, and conceptually amend the

375 call for non-territorial, topological and relational approaches to conceptualising

376 spatiality. However in the context of this paper, there are four notable

377 observations to make.

378 First, the momentum behind relational perspectives remains as strong

379 today as it has over the past decade, with many of the same scholars who

380 were influential in its development continuing to push the agenda forward (see

381 Geografiska Annaler 2004, Massey 2005, 2007). Indeed, a decade on from

382 their pioneering study of south east England (with Massey), Allen and

383 Cochrane's (2007) latest contribution epitomise this as they reprise their

384 longstanding interest with the south east region to further develop their 
argument for a topological understanding of state spatiality - one that goes some way to explaining the 'politics of scale' as the outcome of an assemblage of actors (public, private, central, regional, global) 'lodged' in national territories, but not bound by them. This is a conceptual debate that is clearly not going away in the immediate future. Moreover, it has fanned the 390 flames for other debates to take flight in recent years. The concept of 'scale' has been a key talking point for geographers for nearly three decades now. In this time, ongoing discussions between different intellectual camps have led to a number of important intellectual 394 developments (for overviews see Herod and Wright, 2002; Sheppard and 395 McMaster, 2004). No more was this the case than in 2005 when Marston et al 396 called for a 'human geography without scale' (Marston et al 2005). A bold 397 step, Marston et al took the (relational) argument that if places (e.g. regions) 398 are thought of as the effects of a myriad of social and material networks made 399 up of complex geographies that are not territorially bound, this also expunges 400 the idea that places (e.g. regions) can be framed as/at distinct spatial scales. 401 Proposing a 'flat ontology' as the basis for sociospatial investigation, Marston 402 et al's (2005) vision of a human geography without scale is providing the basis 403 for much debate (for a flavour see Jonas 2006, Jones et al 2007).

404 Somewhat related to this, but developed from a different origin, 405 Mansfield (2005) added a third dimension to arguments levelled against the 406 work of Brenner and other strategic-relational theorists. Arguing against the 407 prevailing trend amongst scholars of globalization and neoliberalism to turn 408 away from the national as a relevant scale as it is 'rescaled' to local, regional 409 and global scales, Mansfield suggests the need to move beyond the notion of 
410 'rescaling' to recognize that the national remains relevant in contemporary

411 political economy. For Mansfield (2005, 458), "the rescaling argument treats

412 the national largely as residual, which serves to draw our attention away from

413 complex scalar practices without offering a truly different way of thinking about

414 scalar relations". Given that the strategic-relational approach was lauded for

415 navigating the new regionalism away from its critical points of weakness, it is

416 revealing to note that (albeit in a different context) it too stands accused of not

417 fully recognising the national in contemporary political economy.

$418 \quad$ While Jones and MacLeod's (2004) suggestion that relational accounts

419 are most convincing when they focus on 'economic flows', the fourth 420 development has seen Amin et al (2003) articulate their vision of a future 421 based on a 'relational grammar of politics'. Extending the notion of the 422 'relational region', Amin et al further challenge conventional 423 conceptualisations of regions by suggesting the need to replace the territorial 424 politics of devolution - the result of policies devised during the 1990s to 425 devolve decision-making and associated policy implementation to regional 426 institutions in line with thinking around the new regionalism - with a 'politics of 427 dispersal' in what they consider to be "an era of increasingly geographically 428 extended spatial flows and an intellectual context where space is frequently 429 being imagined as a product of networks and relations, in contrast to an older 430 topography in which territoriality was dominant" $(2003,6)$. Developed in the 431 context of the British state, Amin et al take issue with the programmed 432 devolution of powers to politically and administratively bounded regions, 433 arguing that it does little to address the widespread inequality that exists 434 between the regions. Critiquing the new regionalism and its claim that there is 
435 a link between the region and economic competitiveness and democratic 436 renewal, Amin et al proposed a radical change to the spatial geometry of the 437 British state based upon an advocacy of relational approaches to 438 conceptualizing state spatiality. Notwithstanding the arguments as to the 439 various merits of such a radical change to the spatial geometry of the British 440 state, Amin et al provide a thought-provoking insight into the scope for 441 relational perspectives to filter into future political praxis - and by implication 442 the future of the region in political economy (cf. Allen and Cochrane 2007).

$443 \quad$ Yet if Amin et al's drift into the realm of informed theoretical speculation 444 appears far removed from a policy template ready for immediate 445 implementation, the latest policy developments across North America and 446 Western Europe do suggest that relational perspectives are both informing 447 and reflecting recent political praxis. Most notable in this regard has been the 448 re-emergence of the 'city-region concept' and the rise of a 'new city449 regionalism' in political economy.

451 The rise of the city-region concept in political economy

452 A point of departure for the new regionalism has been the observation in 453 recent years that the so-called 'rise of the region' to coincided with the 454 resurgence of another spatial form - the city. Under the titles of 'global city455 regions' (Scott 2001) and the 'new' city regionalism (Ward and Jonas 2004), 456 there has been increased support for a resurgence of city-regions in political 457 economy such that they have come to "function as the basic motors of the 458 global economy" and "territorial platforms for much of the post-Fordist 459 economy" (Scott 2001, 4). Where a decade ago it was regions, recognition 
that city-regions are seen to be competitive territories par excellence is clearly

461 important, but perhaps more important is what it reflects in relation to the

462 connection made between cities and regions in the politics of subnational

463 economic development and governance. Important questions arising include,

464 but are not limited to: What is the relationship between regions and city-

465 regions? Are regions non-city-regions? Are there theoretical differences

466 between regions and city-regions? If so, does this reflect a different and/or

467 alternative conceptualisation of state spatiality? Is the city-region a genuine

468 threat to the region - or are they complementary? And finally, what political

469 implications pertain from this?

470 In the first instance, the language that has accompanied the advance of

471 city-regions in political economy has strong relational undertones. Where

472 regions were presented to be by and large territorially bounded political-

473 administrative units in the new regionalism, the literature on the new city-

474 regionalism has been quick to emphasise how "the geographic structure of

475 these networks tends more and more to override purely political boundaries"

476 such that city-regions are open, porous spaces, easily permeated by flows of

477 capital, knowledge, and finance, and increasingly free from regulatory control

478 on the part of national states (Scott 2001, 4). Symbolic of a broader shift in

479 conceptualising spatiality from a framework based upon 'spaces of places'

480 (territory) to one centred on 'spaces of flows' (networks) (Castells 1996), here

481 too it can be argued that the latest transition in the regulation and governance

482 of the capitalist system, reflected in and of recent political praxis around city-

483 regions, has served to reinforce the call for relational approaches to

484 conceptualising spatiality. 
All of which could suggest that the city-region is a genuine threat to the region as it presently stands. Yet the new orthodoxy surrounding the cityregion is itself the focus of much debate. For it can be argued, pace Jones and MacLeod (2004), that the new city-regionalism has been at its most 489 convincing when focusing on the economic rationale for city-region 490 development, with a tendency to reify the city-region as an agent of wealth 491 creation and redistribution. More than this there has been an under-emphasis 492 in the literature on how city-regions "are constructed politically and reproduced 493 through everyday acts and struggles around consumption and social 494 reproduction" with a notable lacuna being "serious treatment of the role of the 495 state and an associated politics of distribution constructed around various 496 sites, spaces and scales across the city-region" (Jonas and Ward 2007, 170). 497 Not surprisingly then, the city-region concept has become the subject of much 498 debate in recent months, with the International Journal of Urban and Regional 499 Research and the Journal of Economic Geography both setting up forums for 500 debate - the former on extending the economic logic of city-region 501 development to argue the need to conceptualize the emergence of 'city502 regions' as the product of a particular set of economic, cultural, environmental 503 and political projects, each with their own logics (IJURR 2007; Harding 2007, 504 Ward and Jonas, 2007); the latter on the argument that much of what has 505 been said about city-regions appears as a reworking of what was said 506 previously about regions a decade earlier, and critically, that the same points 507 of weakness which undermined the new regionalism appear to have been 508 collapsed into the new city-regionalism (Harrison 2007). Having opened the 509 city-region concept up for debate, what first appeared as a potential threat to 
510 the regional concept has now become a potential opportunity through which

511 urban and regional geographers can work together to further connect the new

512 politics of economic development with transitions in the regulation and

513 governance of contemporary capitalism and its spatial form.

514

515 Concluding comments: the era of 'relational regionalism'?

516 This paper has sought to critically analyse the position, role and function of

517 the region in political economy. In doing this, the paper has made a number of

518 observations. First, the regional concept is not the hot topic that it was a

519 decade ago. Gone has the orthodoxy that surrounded the new regionalism to

520 be replaced by a series of new and currently in vogue perspectives within

521 political economy. Theoretically the conceptualisation of regions as

522 territorial/scalar has been challenged by relational perspectives that advocate

523 conceptualising spatiality as networked/topological, while politically, the region

524 has been challenged by the re-emergence of the city-region concept. At first

525 sight, each presents itself as a threat to the regional concept, and yet each

526 time the regional concept has been under threat previously it has emerged

527 from these skirmishes a more robust concept. Despite perceived threats

528 generated by the collapse of the new regionalism, the support for relational

529 conceptualisations of spatiality, and the rise of the city-region concept, this

530 paper argues that there is little to suggest that this cannot happen once more.

531 Rather than presupposing the erosion of the regional concept, this

532 paper suggests that these new challenges to the conventional wisdom of what

533 the regional concept stands for could foreground the emergence of a new era

534 for regions in political economy - the era of 'relational regionalism'. That the 
535

536

537 future of the region in political economy. One of the main reasons why the 538 regional concept has provided an important backdrop for the advocacy of 539 relational/topological approaches to conceptualising spatiality is precisely 540 because the orthodoxy surrounding the new regionalism provided an easy 541 target for critique. This, along with broader concerns with territorial/scalar 542 approaches in political economy, has promoted debate on a number of issues 543 for which regional geography has subsequently become an important 544 backdrop: the changing nature of state space under modern capitalism; the 545 transformation of state space under conditions of globalization (in particular 546 the role of cities and regions in globalization); conceptualising spatiality with or 547 without scale; state rescaling or the need to move beyond notions of 548 rescaling; conceptualising spatiality as territorial/scalar and/or

549 networked/topological/relational; the geography of the state; and geographical 550 struggles over democracy, citizenship, and identity. So what of the future for 551 regions in political economy. regional concept appeared at its strongest, what appeared as strengths

554 quickly manifest themselves as weaknesses. More recently, and by the very 555 nature of the attention that has been directed towards the region in recent 556 years, these new debates on conceptualising socio-spatiality have had the 557 potential to inflict a certain degree of damage to the conceptual standing of 558 the region in political economy. But the velocity at which new conceptual 559 understanding is being generated from these theoretical skirmishes could also 
be suggestive of the potential for a more robust regional concept to emerge.

561 Indeed the history of the regional concept in geography might be suggestive

562 of this. For what has often first appeared as a threat or challenge to the

563 conceptual standing of the region has very often provided not only the

564 impetus, but the backbone, for a new era in regional geography. But what of

565 the future?

566

Writing under the heading "Why (for example) regions continue to

567 matter", one suggestion has been that (re)thinking regions along these new

568 lines not only reveals 'the 'inbetween-spaces' of action, which hitherto have

569 been marginalized in work too often preoccupied with global-local binaries,

570 localization/globalization paradoxes or glocalization" but also how,

571

572

573

574

575

576

577

578

579

580

581

582

583

584

585

586

587

588

589

"the 'region' can be seen to operate both as a between space and a mesolevel concept, which is amenable to thinking about a spatial combination of flows, connections, processes, structures, networks, sites, places, settings, agencies and institutions. This 'new regionalism' is not just about trying to explain the production of a particular scale of economic and social life but also represents a new way of approaching 'regions' theoretically as strategic sites in the geography of capitalism after Fordism."

Jonas $(2006,402)$

highlights why the regional concept and regional geography still matter in political economy. More than simply a between space, the interdisciplinary nature of these theoretical, methodological, and political debates sees regional geography provide a unique backdrop, precisely because it is not economic geography, not political geography, not cultural geography, not poststructuralist geography, but a branch of geography which has the capacity to bring scholars with different disciplinary backgrounds together to promote 
interdisciplinary debate on how we conceptualise space. As such, the task

591 scholars faced a decade ago remains the same - to connect the new politics

592 of economic development with transitions in the regulation and governance of

593 contemporary capitalism and its spatial form - but where regions were seen

594 as the answer to the question a decade ago, regions may now be the vehicle

595 by which we can uncover those answers. Indeed it is perhaps worthwhile

596 repeating the thoughts of Thrift, who on the cusp of the 'new regionalism'

597 called 'for a new regional geography' precisely because:

598

“...grouped around the practice of regional geography can be found most of the important problems than human geography faces today. The invocation of regional geography cannot solve these problems but it certainly brings them into focus, and in the act of focusing, it shows us how far we still have to go."

Thrift $(1994,200)$

Quite clearly much work needs to be done before it can be presented in

608 the emergence of a new regional political economy centred on 'relational

609 regionalism'? 
John Harrison is Lecturer in Human Geography at the Department of Geography, Loughborough University, UK. His previous writing has focused on the new regionalism, city-regions, and the political economy of English regional policy. He has authored papers in these areas for the Journal of Economic Geography, Geoforum and Space \& Polity. He holds an MA and PhD form the University of Wales, Aberystwyth.

628

629

630

631

ACKNOWLEDGEMENETS

632

633

634 The author would like to thank Neil Coe and the two anonymous reviewers for 635 their constructive commentaries on an earlier version of the paper.

636

637

638

639

640

641

642 
Allen J and Cochrane A 2007 Beyond the territorial fix: regional assemblages, politics and power Regional Studies 41 1161-1176

Allen J Massey D and Cochrane A 1998 Rethinking the region Routledge, London

651 Amin A 2004 Regions unbound: towards a new politics of place Geografiska Annaler B 86 33-44

653

654

Amin A Massey D and Thrift N 2003 Decentering the nation: a radical approach to regional inequality Catalyst, London

Bache I 1998 The politics of European Union regional policy: multi-level 656 governance or flexible gatekeeping? Sheffield Academic Press, Sheffield

658 Brenner N 2004 New state spaces - urban governance and the rescaling of statehood Oxford University Press, Oxford

660 Brenner N Jessop B Jones M and MacLeod G eds 2003 State-space: a 661 reader Blackwell, Oxford

662 Castells M 1996 The rise of the network society Blackwell, Oxford

663 Chesterton G K 1905/2006 Heretics Reprinted by Dover Books

664 Christopherson S 2003 The limits to "new regionalism": (re)learning from the 665 media industries Geoforum 34 413-415 
Dicken P, Kelly P, Olds K and Yeung H 2001 Chains and networks, territories and scales: towards a relational framework for analysing the global economy Global Networks 1 89-112

Dickinson R 1976 Regional concept: the Anglo-American leaders Routledge and Kegan Paul, London

671 Fleure H J 1919 Human regions Scottish Geographical Magazine 35 94-105

Geografiska Annaler 2004 Special issue - the Vega symposium 86B 1-78

673 Gilbert A 1988 The new regional geography in English and French-speaking countries Progress in Human Geography 12 208-228

675 Haggett P 1965 Locational analysis in human geography Arnold, London

676 Harding A 2007 Taking city regions seriously? Response to debate on cityregions: new geographies of governance, democracy and social reproduction International Journal of Urban and Regional Research 31 443-458.

680 Harrison J 2006 Re-reading the new regionalism: a sympathetic critique 681 Space and Polity 10 21-46

Harrison J 2007 From competitive regions to competitive city-regions: a new orthodoxy, but some old mistakes Journal of Economic Geography 7 $311-332$

Hartshorne R 1939 The nature of geography Annals of the Association of American Geographers, Lancaster

687 Hartshorne R 1959 Perspectives on the nature of geography John Murray, 688 London

689 Harvey D 1982 The limits to capital Blackwell, Oxford 
690 Herberston A 1905 The major natural regions: an essay in systematic geography Geographical Journal 25 300-312

Herod A and Wright M 2002 Geographies of power: placing scale Blackwell, Oxford

694 Holland S 1976 Capital versus the regions Macmillan, London

695 Hooghe L ed 1996 Cohesion policy and European integration: building multilevel governance Oxford University Press, Oxford

Hudson R 2007 Regions and regional uneven development forever? Some reflective comments upon theory and practice Regional Studies 41 $1149-1160$

International Journal of Urban and Regional Research 2007 Introduction to a debate on city regions 31 169-223

Isard W 1960 Methods of regional science Wiley, Chichester

Jonas A 2006 Pro scale: further reflections on the 'scale debate' in human geography Transactions of the Institute of British Geographers 31 399-

Jonas A and Ward K 2007 Introduction to a debate on city-regions: new geographies of governance, democracy and social reproduction International Journal of Urban and Regional Research 31 169-178

Jones J P, Woodward K and Marston S 2007 Situating flatness Transactions of the Institute of British Geographers 32 264-276 'partnerships for prosperity' or new scales of state power? Environment and Planning A 33 1185-1211 
Jones M and MacLeod G 2004 Regional spaces, spaces of regionalism: territory, insurgent politics, and the English question Transactions of the Institute of British Geographers 29 433-452

Keating M 1998 The new regionalism in Western Europe - territorial restructuring and political change Elgar, Cheltenham

Lovering J 1999 Theory led by policy: the inadequacies of the 'new regionalism' (illustrated from the case of Wales) International Journal of Urban and Regional Research 23 379-395

MacLeod G 2001a Beyond soft institutionalism: accumulation, regulation, and their geographical fixes Environment and Planning A 33 1145-1167

MacLeod G 2001b New regionalism reconsidered: globalisation and the remaking of political economic space International Journal of Urban and Regional Research 25 804-829

MacLeod G and Goodwin M 1999a Reconstructing an urban and regional political economy: on the state, politics, scale, and explanation Political Geography 18 697-730

MacLeod G and Goodwin M 1999b Space, scale and state strategy: rethinking urban and regional governance Progress in Human Geography 23 503-527

MacLeod G and Jones M 2001 Renewing the geography of regions Environment and Planning D 19 669-695

MacLeod G and Jones M 2007 Territorial, scalar, networked, connected: In what sense a 'regional world'? Regional Studies 41 1177-1191 
Mansfield B 2005 Beyond rescaling: reintegrating the 'national' as a dimension of scalar relations Progress in Human Geography 29 458473

Marston S Jones J-P and Woodward K 2005 Human geography without scale Transactions of the Institute of British Geographers 30 416-432

Massey D 1978 Regionalism: some current issues Capital and Class 6 106125

Massey D 1979 In what sense a regional problem? Regional Studies 13 233243

Massey D 1984 Spatial divisions of labour Macmillan, London

Massey D 2005 For space Sage, London

Massey D 2007 World city Polity, Cambridge

OECD Territorial Review 2007 Competitive cities in the global economy OECD, Paris regional identity Fennia 16 105-146

Paasi A 1986 The institutionalisation of regions: a theoretical framework for understanding the emergence of regions and the constitution of

Painter J 2007 Cartographic anxiety and the search for regionality Environment and Planning $A$ advance online publication, doi:10.1068/a38255

Paterson J H 1974 Writing regional geography problems in the AngloAmerican realm in Board C Chorley $\mathbf{R} \mathbf{J}$ and Stoddart, D $\mathbf{R}$ Progress in geography: international reviews of current research 6 Arnold, London 
761 Putnam R 1993 Making democracy work: civic traditions in modern Italy Princeton University Press, Princeton

Sayer A 1992 Methods in social science: a realist approach Routledge, London

765

766

767

768

769

770

771

772

773

774

775

776

777

778

779

780

781

782

783

784 production, competition, and political order Oxford University Press, Oxford

Scott A ed 2001 Global city-regions: trends, theory, policy Oxford University Press, Oxford

Scott A and Storper M 2003 Regions, globalization, development Regional Studies 37 579-593

Segbers K eds 2007 The making of global city regions John Hopkins University Press, Baltimore

Sheppard E and McMaster B eds 2004 Scale \& geographic inquiry: nature, society, and method Blackwell, Oxford

Simmonds R and Hack G eds 2000 Global city regions: their emerging forms Spon, London

Storper M 1997 The regional world: territorial development in a global economy Guildford Press, New York

Swyngedouw E 2004 Globalisation or 'glocalisation'? Networks, territories and rescaling Cambridge Review of International Affairs 17 25-48

Thrift N 1994 Taking aim at the heart of the region in Gregory D, Martin R and Smith G eds Human geography: society, space and social science Macmillan, London 200-231 
Vidal de la Blache P 1926 Principles of human geography Constable, London

787 Ward K and Jonas A 2004 Competitive city-regionalism as a politics of space: a critical reinterpretation of the new regionalism Environment and Planning A 36 2119-2139

Ward K and Jonas A 2007 There's more than one way to be 'serious' about city-regions International Journal of Urban and Regional Research 31 $647-656$

\footnotetext{
' There are two important qualifiers. First, this paper will focus primarily on the UK context, and where appropriate, conjoin this with the development of the regional concept internationally. Though acknowledging the centrality of the UK to this paper, it is believed that the nature of the argument made and the universal relevance of the literature discussed is conducive to international appeal. And second, while acknowledging the norm of academic traditions such as international relations theory to use 'region' to define an area comprising more than one nation-state e.g. the Baltic Sea Region or the Middle East, this paper will deal solely with subnational forms of region.
} 